\title{
Multi-channel analysis of surface wave method for geotechnical site characterization in Yogyakarta, Indonesia
}

\author{
Nwai Le Ngal ${ }^{1, *}$, Subagyo Pramumijoyo ${ }^{2}$, Iman Satyarno $^{3}$, Kirbani Sri Brotopuspito ${ }^{4}$, Junji Kiyono ${ }^{5}$, and Eddy Hartantyo ${ }^{4}$ \\ ${ }^{1}$ Department of Geology, University of Yangon, Yangon, Myanmar \\ ${ }^{2}$ Department of Geological Engineering, Universitas Gadjah Mada, Yogyakarta, Indonesia \\ ${ }^{3}$ Department of Civil and Environmental Engineering, Universitas Gadjah Mada, Yogyakarta, Indonesia \\ ${ }^{4}$ Department of Physics, Universitas Gadjah Mada, Yogyakarta, Indonesia \\ ${ }^{5}$ Department of Urban Management, Kyoto University, Kyoto, Japan
}

\begin{abstract}
On May $27^{\text {th }}$ 2006, Yogyakarta earthquake happened with $6.3 \mathrm{Mw}$. It was causing widespread destruction and loss of life and property. The average shear wave velocity to $30 \mathrm{~m}$ (Vs30) is useful parameter for classifying sites to predict their potential to amplify seismic shaking (Boore, 2004) [1]. Shear wave velocity is one of the most influential factors of the ground motion. The average shear wave velocity for the top $30 \mathrm{~m}$ of soil is referred to as Vs30. In this study, the Vs30 values were calculated by using multichannel analysis of surface waves (MASW) method. The Multichannel Analysis of Surface Waves (MASW) method was introduced by Park et al. (1999). Multi-channel Analysis of Surface Waves (MASW) is non-invasive method of estimating the shear-wave velocity profile. It utilizes the dispersive properties of Rayleigh waves for imaging the subsurface layers. MASW surveys can be divided into active and passive surveys. In active MASW method, surface waves can be easily generated by an impulsive source like a hammer, sledge hammer, weight drops, accelerated weight drops and explosive. Seismic measurements were carried out 44 locations in Yogyakarta province, in Indonesia. The dispersion data of the recorded Rayleigh waves were processed by using Seisimager software to obtain shear wave velocity profiles of the studied area. The average shear wave velocities of the soil obtained are ranging from $200 \mathrm{~ms}-1$ to $988 \mathrm{~ms}-1$, respectively.
\end{abstract}

\section{Introduction}

Yogyakarta is one of the high seismicity areas in Indonesia. Yogyakarta earthquake occurred with $6.3 \mathrm{Mw}$ on $27^{\text {th }}$ May 2006. Although, the magnitude is not too large, the earthquake destroyed more than 60,000 houses in the city, about 6000 people were killed, and 50,000 were injured. The Yogyakarta province is high density of population.

The Vs30 is considered as an important parameter for site class characterization in earthquake resistant design and site dependent, building-code provisions [1-3]. The average shear wave velocity (Vs30) is to determine the shear wave velocity in the upper $30 \mathrm{~m}$ of the ground surface. The shear wave velocity (Vs) of the sub-surface layer can be estimated using various seismic methods. In this study, multi-channel analysis of surface wave (MASW) method was utilized for site characterization.se A4 paper size $(210 \times 297 \mathrm{~mm})$ and adjust the margins to those shown in Table 1. The final printed area will be $172 \times 252 \mathrm{~mm}$.

\section{General geology of Yogyakarta}

The distinctive lithologic units in this area (Yogyakarta) are Semilir Formation, Nglanggran Formation, Sambiputu Formation, Kepek Formation, Wonosari
Formation, Sentolo Formation, Young volcanic deposits of Merapi volcano (Valley-filled deposits) and recent Alluvium (Figure 1) [4-5]. Semilir Formation is mainly composed of interbedded breccias, shales and tuffs. The age of this formation is Late Oligocene to early Miocene. The Nglanggran Formation mainly composed of coarsed volcanic materials such as andesitic breccias which grade upward into pebble conglomerates and andesitic sandstones.

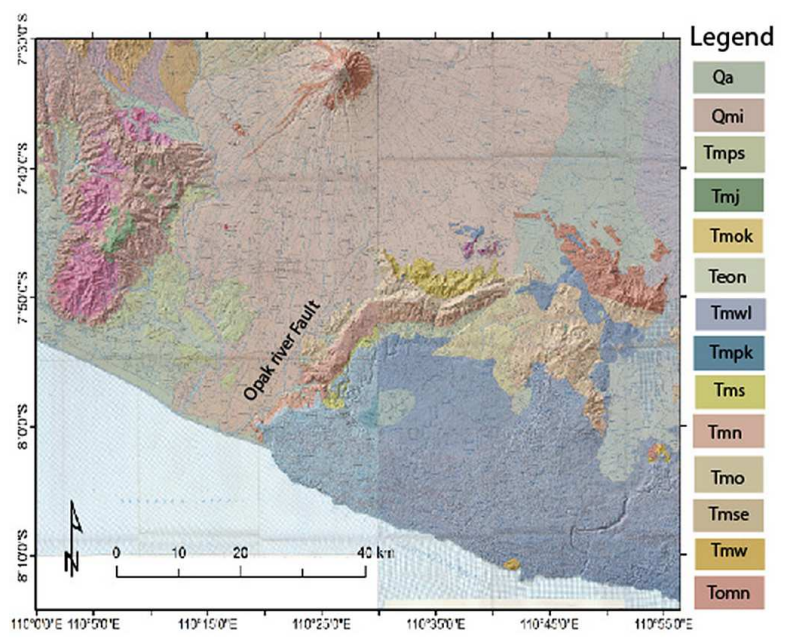

Fig. 1. Geological map of the Yogyakarta area $[4,5]$.

\footnotetext{
* Corresponding author: nwai.nln@gmail.com
} 
The age of this Formation is Early Miocene to Middle Miocene. Sambiputu Formation comprises of thick series of well bedded marine sandstones, siltstones and claystones with well define turbiditic characters. The age of this formation is Middle Miocene. Sentolo Formation is predominantly composed of limestones and marly sandstone. This formation is Middle Miocene to Pliocene in age. Wonosari Formation mainly consists of limestone facies as reef limestone, calcarenite and tuffaceous calcarenite, ranging in age from Middle Miocene to the Lower Pliocene. Kepek Formation is mainly composed of marl and bedded limestone. It is Upper Miocene to Pliocene in age. Young volcanic deposits of Merapi volcano are predominantly composed of andesite lavas and tuffs. The age of Young Merapi Volcanics is Holocene. The recent alluvium comprises of fine to coarse grained sands, gravel, silt and clay can be occurred along larger streams and coastal plain. The age is probably Upper Holocene.

\section{Multi-channel analysis of surface wave method}

The surface wave methods were used since the last several decades [6-9]. The Multichannel Analysis of Surface Waves (MASW) method was introduced by [10]. Multi-Channel Analysis of Surface Waves (MASW) is non-invasive method of estimating the shear-wave velocity profile. It utilizes the dispersive properties of Rayleigh waves for imaging the subsurface layers. There are two types of MASW survey method which are Active method and Passive method. In active MASW method, surface waves can be easily generated by an impulsive source like a hammer, sledge hammer, weight drops, accelerated weight drops and explosive. While passive surface waves are generated by cultural activities and natural source, such as traffic and tidal motion. The entire procedure for MASW consists of three steps: (a) acquiring multi-channel field records; (b) extracting dispersion curves (c) inverting these dispersion curves to obtain 1-D (depth) Vs profiles [11].

The multichannel analysis of surface waves (MASW) survey was performed at 44 sites in Yogyakarta area. The multichannel analysis of surface wave survey site locations as shown in Figure 2. The equipment for MASW measurement is shown in Figure 3.

For the MASW surveys, the 24-channel geophone was used as lined up in a straight line on the surface of the test site. Generally, to get the higher resolution dispersion image, the number of geophones need to be increased [12]. The natural frequency of each geophone is $4.5 \mathrm{~Hz}$. The geophone spacing is $2 \mathrm{~m}$ apart were used to record seismic wave and the total length of the spread was $46 \mathrm{~m}$ (Figure 4).

The shot points were placed at $2 \mathrm{~m}$ distance offset at the starting line and at the end of survey line. A $10 \mathrm{~kg}$ hammer was used as a source of active MASW. The recording time was $2000 \mathrm{~ms}$, and the sampling rate was $1 \mathrm{~ms}$. The recorded data format is "SGY" format.

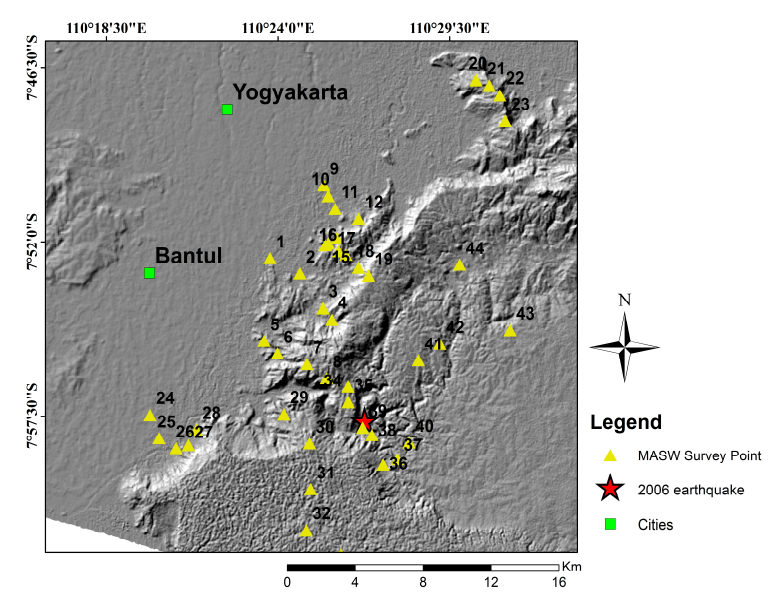

Fig. 2. MASW survey location map.

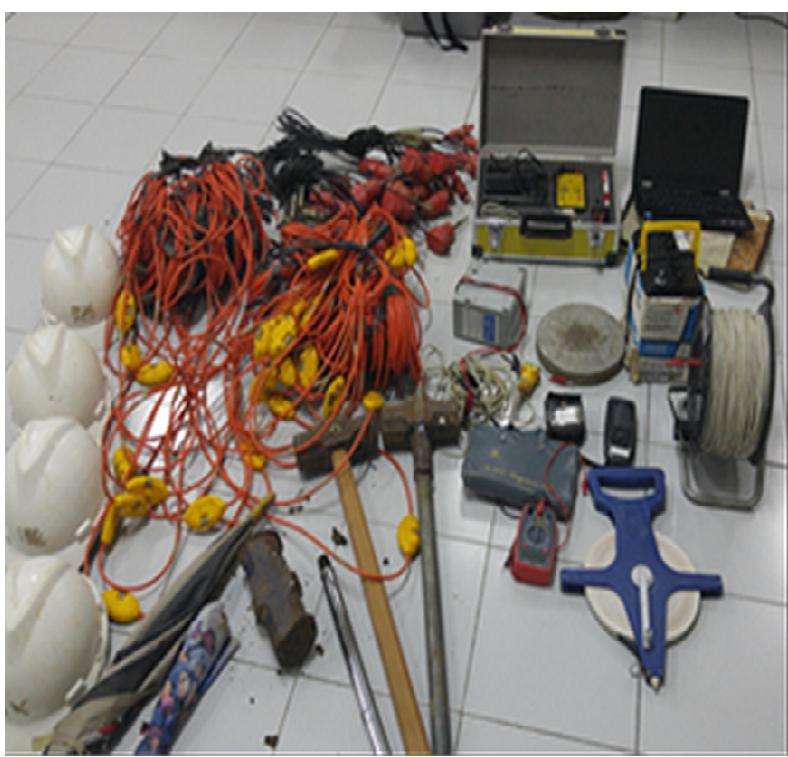

Fig. 3. Equipment of MASW method.

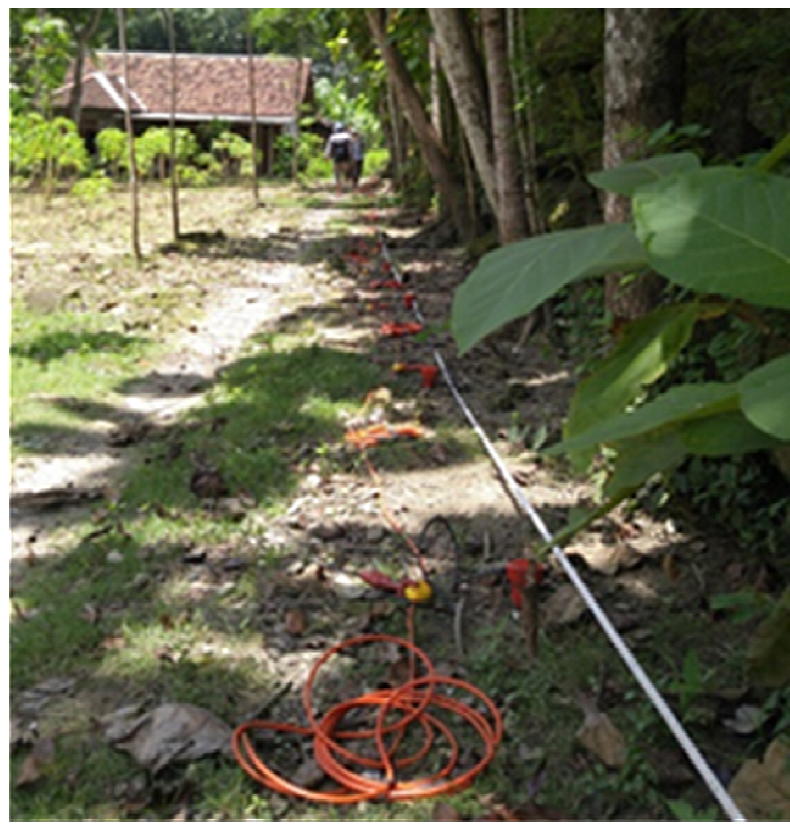

Fig. 4. Example of the geophone configuration. 
The advantages of the MASW method included that the dispersion analysis involved in MASW is faster and easier for processing. The data from all receivers can be processed at once time. The MASW method is cost and time effective to estimate the shear wave velocity profile.

\section{Results and discussions}

The processing can be done using different kind of software to get surface wave dispersion curve and shear wave velocity profile. In this study, the MASW data was processed by using Seisimager software [13]. The entire procedure of generating $\mathrm{v}_{\mathrm{s}}$ profile consists of three steps: acquiring ground roll data in the field, processing the data to determine dispersion curve (a plot of frequency vs. phase velocity), and the extraction of $\mathrm{v}_{\mathrm{s}}$ profile from the dispersion curve (Figure 5).

In the present study, the near-surface materials are characterized based on the $\mathrm{V}_{\mathrm{s}}{ }^{30}[14-15]$ as could be seen in Table 1.

The values of $\mathrm{V}_{\mathrm{s}}{ }^{30}$ are high for the eastern parts of the city, while it is relatively low $\mathrm{V}_{\mathrm{s}}{ }^{30}$ value for the Yogyakarta city as shown in Fig.6. In Figure 6, the dark blue colour is showing soil class $\mathrm{D}$, the purple colour is representing soil class $\mathrm{C}$ and the light purple colour is for soil class B.

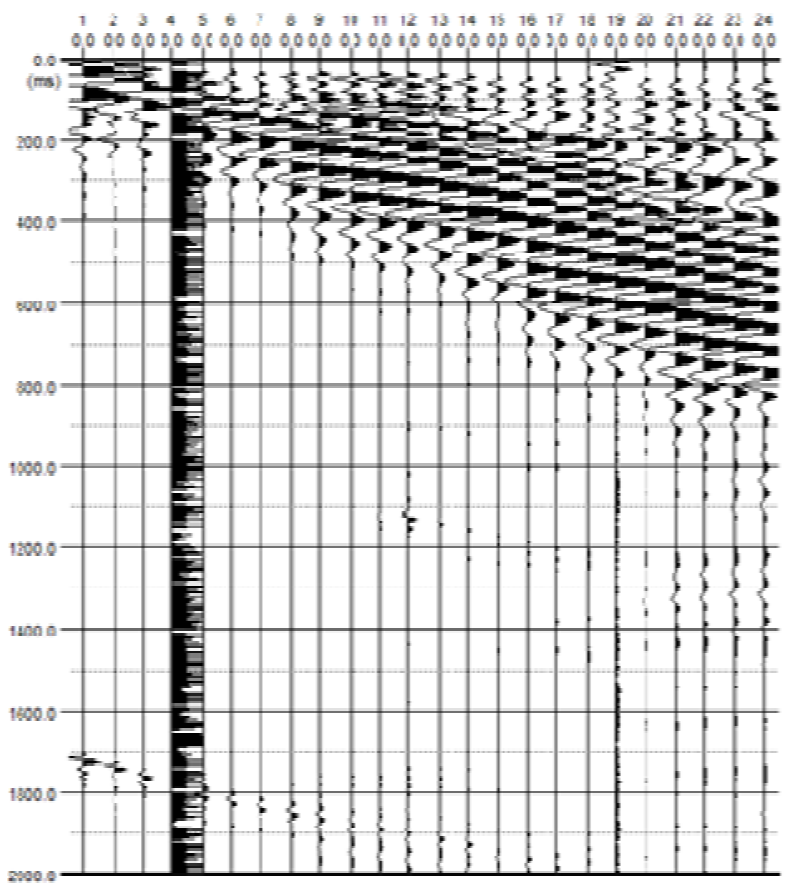

(a)

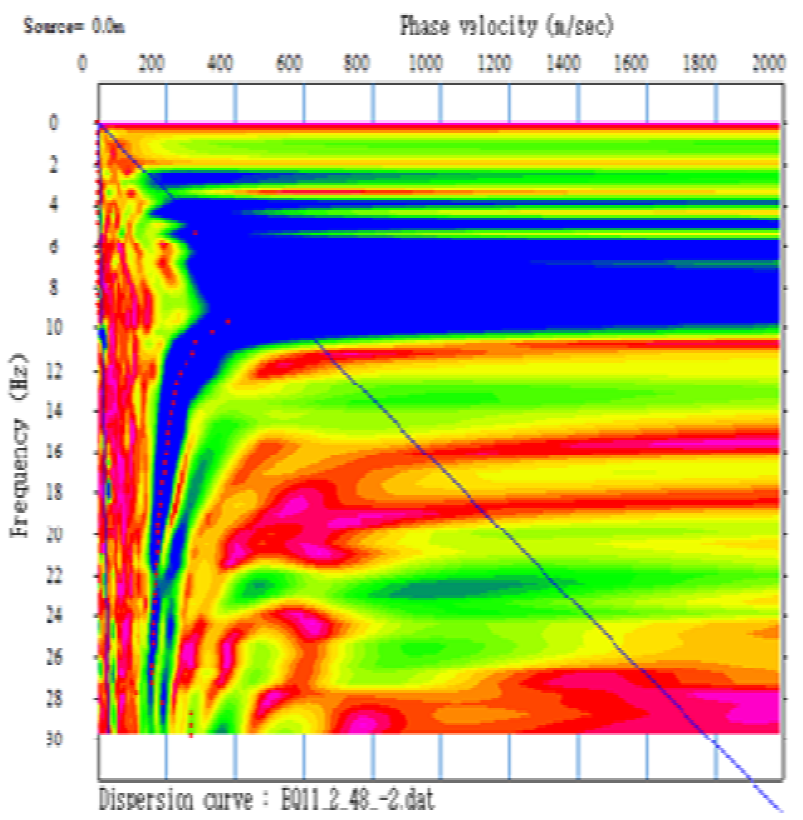

(b)

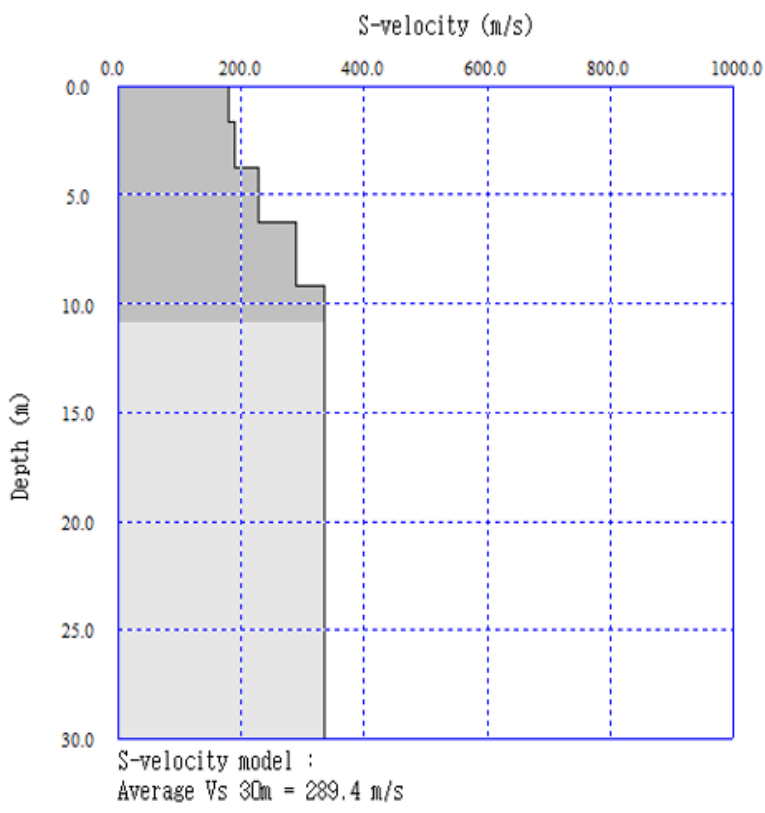

(c)

Fig. 5. (a) Surface wave example from MASW survey (b) dispersion curve (c) shear-wave velocity profile. 
Table. 1 Site classification according to the NEHRP code (Building Seismic Safety Council, 2003) and Indonesia code SNI 1726-2012

\begin{tabular}{|c|l|c|l|c|}
\hline \multirow{2}{*}{$\begin{array}{c}\text { Site } \\
\text { Classi- } \\
\text { fication }\end{array}$} & \multicolumn{2}{|c|}{ NEHRP Code (2003) } & \multicolumn{2}{c|}{$\begin{array}{c}\text { Indonesia Code SNI } \\
\mathbf{1 7 2 6 - 2 0 1 2}\end{array}$} \\
\cline { 2 - 5 } & $\begin{array}{c}\text { Soil } \\
\text { description }\end{array}$ & $\begin{array}{c}\text { Vs30 } \\
(\mathbf{m} / \mathbf{s})\end{array}$ & $\begin{array}{c}\text { Soil } \\
\text { description }\end{array}$ & $\begin{array}{c}\text { Vs30 } \\
\mathbf{( m / s )}\end{array}$ \\
\hline A & Hard Rock & $>1500$ & Hard Rock & $>1500$ \\
\hline \multirow{2}{*}{ B } & Rock & $760-$ & Rock & $750-$ \\
& & 1500 & 1500 \\
\hline \multirow{2}{*}{ C } & Very dense soil & $360-$ & Very dense & $350-$ \\
& & 160 & soil & 750 \\
\hline \multirow{2}{*}{ D } & Stiff soil & $360-$ & Stiff soil & $175-$ \\
\hline E & Soft soil & $<180$ & Soft soil & $<175$ \\
\hline
\end{tabular}

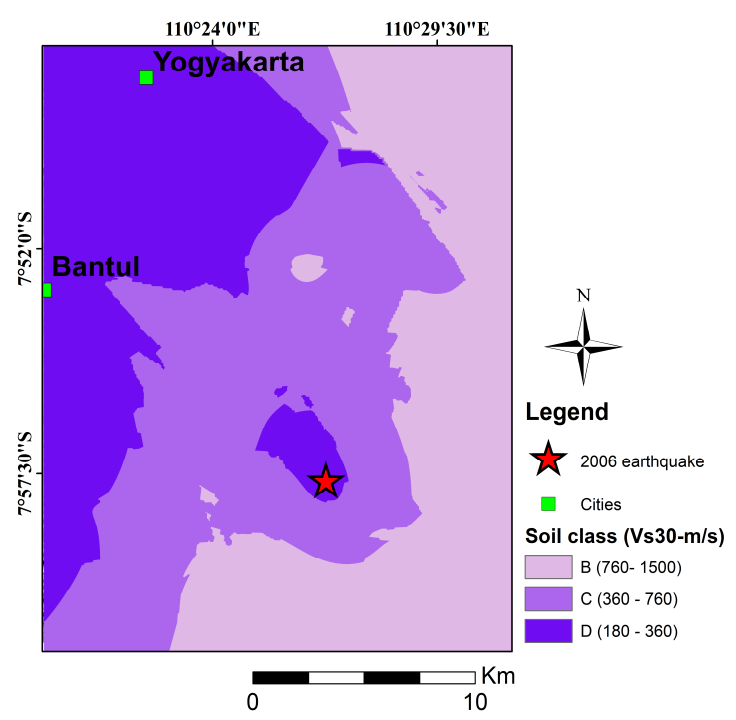

Fig. 6. Average shear wave velocity distribution map to the depth of $30 \mathrm{~m}$.

\section{Conclusions}

This paper focuses on geotechnical site characterization by Multichannel Analysis of Surface Wave (MASW) survey. In multichannel analysis of surface waves (MASW) method, the shear wave velocity is estimated from the inversion of the dispersion curves of the surface waves (Rayleigh waves). It is one of non-invasive and cost-effective method to estimate the shear wave velocity. This method is very suitable for not allowing invasive tests area. Shear wave velocity is an important parameter for earthquake geotechnical engineering related studies. The $\mathrm{V}_{\mathrm{s}}{ }^{30}$ of the research area is varies from $200 \mathrm{~m} / \mathrm{s}$ to $988 \mathrm{~m} / \mathrm{s}$. So, the soil class is ranging from class B to class D. Many building codes use the average shear wave velocity $\mathrm{V}_{\mathrm{s}}{ }^{30}$ profile. These shear wave velocity value can be used for further seismic hazard analysis.
The authors would like to thank to JICA (Japan International Cooperation Agency) and AUN/SEED-Network (ASEAN University Network/Southeast Asia Engineering Development Network) for financial support to carry out this research. I wish to express my special thanks to all friends from Geological Engineering Department, Geophysics Department and Civil and Environmental Engineering Department, Universitas Gadjah Mada, who help me during my MASW surveying.

\section{References}

1. Boore, D. M ., Estimating Vs(30) or NEHRP Site Classes from shallow velocity models depths $30 \mathrm{~m}$, Bull. Seism. Soc. Am. 94, 591-597(2004)

2. Borcherdt, R.D., Estimates of site-dependent response spectra for design. Earthquake Spectra 10, 617-653 (1994)

3. Anderson,, J.G., Lee, Y., Zeng, Y., Day, S., Control of strong motion by the upper 30 meters. Bull. Seismol. Soc. Am. 86, 1749-1759 (1996)

4. Rahardjo, W., Sukandarrumidi., and Rosidi, H.M.D., Geological Map of the Jogjakarta sheet, Jawa. Scale 1: 100,000, Geological Research and Development Center, Bandung (1995)

5. Surono., Toha dan.B., and Sudarno.I., Geological Map of the Surakarta sheet, Jawa. Scale 1: 100,000, Geological Research and Development Center, Bandung (1992)

6. Aki, K., 1957. Space and time spectra of stationary stochastic waves, with special reference to microtremors. Bull. Earthquke Res. Inst. 35, 415456 (1957)

7. Crampin, S., Bath, M., Higher modes of seismic surface waves: mode separation. Geophys. J. Int. 10, 81-92. http://dx.doi.org/10.1111/j.1365-246X.1965. tb03053.x $(1965)$

8. Nazarian, S., Stokoe II, K.H., Hudson,W.R., Use of spectral analysis of surface waves method for determination of moduli and thicknesses of pavement systems: transport. Res. Rec. 930, 38-45 (1983)

9. Horike, M., Inversion of phase velocity of long period microtremors to the S-wave velocity structure down to the basement in urbanized areas. J. Phys. Earth 33, 59-96 (1985) http://dx.doi.org/10.4294/jpe1952.33.59.

10. Park, C. B., Miller, R. D. \& Xia, J. Multichannel analysis of surface waves(MASW). Geophysics, 64 (3), 800-808 (1999)

11. Park, C. B., Miller, R. D., Xia, J. and Ivanov, J. Multichannel analysis of surface waves (MASW) active and passive methods. The Leading Edge, 26 (1), 60-64 (2007)

12. Park, C. B., Miller, R. D. \& Xia, J. Offset and resolution of dispersion curve in multichannel analysis of surface waves (MASW). Proceedings of the Symposium on the Application of Geophysics to Engineering and Environmental Problems (SAGEEP 2001), Denver, Colorado, SSM-4 (2001) 
13. SeisImager/SW Manual, Windows software for analysis of surface waves. Pickwin v. 3.2, WaveEq v. 2.2 and GeoPlot v. 8.2.5. Manual v. 2.2 (2006)

14. Building Seismic Safety Council, NEHRP Recommended Provisions for Seismic Regulations for New Buildings and Other Structures, Part: Provisions, FEMA 450. Federal Emergency Management Agency, Washington, D. C (2003)

15. National Standardization Agency, SNI 1726. Planning procedures for the earthquake resistance of building structure. 